\title{
MEDIATING ENTREPRENEURIAL CREATIVITY - THE EFFECT OF HUMAN RESOURCE PRACTICES ON INNOVATION
}

\author{
JULIANSYAH NOOR* \\ Departement of Management, School of Economic La Tansa Mashiro, Indonesia
}

\author{
MUSA ALKADHIM ALHABSHY \\ Departement of Management, Universitas Jayabaya, Indonesia
}

MOHD RAFI BIN YAACOB

Faculty of Entrepreneurship and Business, Universiti Malaysia Kelantan, Malaysia

*Corresponding Author: profjul.noor@gmail.com

\begin{abstract}
This research aims to evaluate the link between human resource practices (HRPs) and innovation with mediating effect of entrepreneurial creativity. This research uses the hierarchical analysis to examine data collected from entrepreneurs running 172 small and medium enterprises. The results show that (a) HRPs have a positive and significant effect on entrepreneurial creativity; (b) HRPs have statistically significant impact on innovation. These results provide empirical evidence that entrepreneurial creativity mediates the relationship between HRPs and innovation. Also, the findings provide evidence that the mediating role of entrepreneurial creativity improves employees' innovation. By providing a cross-sectional examination of our model, we showed that HRPs and entrepreneurial creativity are of essence in shaping an innovative context. A comprehensive view on the triggers and outcomes of entrepreneurial creativity and innovation are needed, as the traditional unidirectional cause-effect rationale short in explaining how these concepts relate to one another and to entrepreneur experiences of HRPs.
\end{abstract}

Keywords: Human resource practices, Entrepreneurial creativity, Innovation

Received: $21 / 2 / 2018$

Revised: $26 / 4 / 2018$

Accepted: 18/7/2018

Published: 14/7/2019

\section{Introduction}

The human resource management literature recognizes that innovation assists small and medium enterprises (SMEs) in creating value and sustainable competitive advantage in rapidly changing business environments (Terziovski, 2010; Gronum, Verreynne, and Kastelle, 2012). The SME entrepreneur needs to react to environmental change and develop new skills to enable their firm to achieve the best performance possible (Edwards, Delbridge, \& Munday, 2005). Innovation arises from valuable knowledge, skills, and ability, \& is crucial in the creation of value (Colombo, Piva, and Rossi-Lamastra, 2014). The SME entrepreneur has been described as a creativity source (Valaei \& Rezaeib, 2017). Man, Lau, and Chan (2002, p.124) recognize that entrepreneurial 
creativity is an intangible asset that depends on the "personality traits, skills knowledge, and abilities of the entrepreneur."

Human resource practices (HRPs) affect skills, attitudes, and talents at work and, consequently, the achievement of organizational goals (Cooke, Saini, \& Wang, 2014). The previous literature has addressed several of the factors that influence HRPs and organizational outcomes such as efficiency, institutional culture, and innovation (Cooke et al., 2014; Laursen \& Foss, 2003; Ismaila et al.,2017). This research intends to expand knowledge of the influential factors and will test the relationship between HRPs and innovation from a creativity perspective.

For innovation to be sustainable, SME entrepreneurs need to use human capital to build organizational craftsmanship to create products and services. However, craftsmanship is more complicated than HRPs merely assigning individuals to specific areas (Chang, Gong, \& Shum, 2011). Human resource practices require individuals to improve their performance to improve organizational performance. Generally, SME entrepreneurs implement HRPs to increase employee motivation in relation to organizational development and innovation improvement (De Winne and Sels, 2010). Therefore, it can be state that HRPs encourage innovative activities because SME entrepreneurs need to find and use creativity, innovation, and expertise within their organization in order to succeed (Anderson, Potočnik, \& Zhou, 2014).

However, for innovation, creativity must preexist in the available human capital; SME entrepreneurs cannot merely transfer creativity between individual employees (Alpkan, Bulut, Gunday, Ulusoy, \& Kilic, 2010). Although SME entrepreneurs have access to employee creativity, ability, and skills, entrepreneurs need to have excellent skills in managing creativity to ensure the effective utilization of the creativity within their human resources to foster innovation. Creativity can add value via new ideas through exploiting individual skills (Anderson et al., 2014).

The above studies suggest that HRPs is an important component in the field of human resources management, particularly in trying to better understand the context of the Indonesian organizations and entrepreneurs managing the SME. This implies that HRPs could affect the success of entrepreneurial creativity in trying to achieve its the new innovation. While this may be true, the innovation of the Indonesian entrepreneurs in the SME is also essential to ensure the successful implementation of the organizational policies and plans. It is said, that while shaping the appropriate HRPs that is important to the SME, ensuring the necessary entrepreneurial creativity level among Indonesian entrepreneurs are unequivocally important so as to ensure successful innovation. Thus, this study aims to test the effect of entrepreneurial creativity as a mediator between HRPs and innovation.

\section{Literature Review and Hypothesis Development}

\section{Human Resources Practices}

Small and medium enterprises need to implement HRPs to gain and retain competitive advantage. Some researchers have focused on human resource determinants (Hotho \& Champion, 2011). Jiang, Wang, \& Zhao (2014) posit that there is a relationship between organizational structure, environmental characteristics, and HR innovation. The results show that HRM practices play a role in HR innovation in Chinese organizations (Jiang et al., 2014). As regards organizational factors, Gunday et al. (2011) use four measures - recruitment, organizational structure, compensation, and training and development - to reflect HR innovative, and their results show that HR innovation is positively related to increased productivity. 
Likewise, De Jong and Hartog (2010) prove that the productivity effects of HR innovation using a variety of measures for HR innovative, namely salary incentives, work team, job assignment flexibility, job security, communications, and development (De Jong \& Hartog, 2010).

Previous studies have tested the influence of HRPs on behavioural outcomes, and among these several scholars have examined the impact of HRPs on creativity (Jiang et al., 2014) and innovation (Anderson et al., 2014). However, previous studies did not look at entrepreneur activity. Therefore, the HRP measurement differs between previous studies and the current study to answer the objectives of this study. This study suggests that the effect of HRPs on innovation is determined through entrepreneurial creativity. This study follows previous research that uses the concept of human resources and innovative practices (Youndt, Snell, Dean, \& Lepak, 1996; Terziovski, 2010; Anderson et al., 2014; De Jong and Hartog, 2010) because this concept is closer to the topic of HRPs, management, and innovation. This research considers the following four dimensions of HRPs: compensation, recruitment, performance appraisal, and training and development.

\section{Human Resource Practices and Innovation}

Entrepreneurial creativity is a source of competitive advantage and social processes and is an SME resource (Chaston \& Sadler-Smith, 2012; Perry-Smith, 2006). Creativity empowers SMEs to increase their competence and find opportunities for innovation (Gimmon \& Levie, 2010; Storper \& Scott, 2009; McAdam, Moffett, Hazlett, \& Shevlin, 2010). Currently, SMEs promote new products and improve management processes. They need creative concepts, innovative approaches, and new opportunities (Perry-Smith, 2006). HPRs influence the attitudes, abilities, and skills of employees in order to achieve organizational goals (Herzog, 2010). Also, Sheehan (2014) and Ait Razouk
(2011) state that commitment and involvement affect creative thinking and creativity. Thus, this research shows that HRPs influence innovation.

Small and medium enterprises need to develop innovation activities, but SMEs as employers face uncertainty in the innovation process (Voss \& Voss, 2013). Moreover, they need creative employees who are adaptable, risk-taking, and understanding of risk and uncertainty (Stjernholm Madsen \& Olhoy, 2005). Thus, SMEs place emphasis on employee characteristics such as creative abilities and innovative capabilities in their selection criteria during the recruitment process. They are expected to produce a variety of concepts and engage in more innovation behaviors (Chen \& Huang, 2009). Innovation as a concept is somewhat nebulous and involves many aspects and components, so while innovation is of value and a key priority for SMEs it is important that there is a formal assessment mechanism in place in SMEs for measuring behaviour and innovation outcomes (Grimaldi, Quinto, \& Reba, 2013). An essential incentive for intrapreneurial staff is the performance appraisal because it create challenges and feelings of achievement (Ait Razouk, 2011). Performance evaluation increases the motivation of intrapreneurial staff involved in innovative activities, which results in SMEs achieving a good level of innovation (Jimenez-Jimenez and Sanz-Valle, 2005). Individual achievement that is recognized through some form of compensation also encourages innovation. Previous studies have shown that SMEs use HRPs to influence intrapreneurial behaviours and to add more value to innovation development through compensation, recruitment, training and development, and performance appraisal. Small and medium enterprises can increase their capacity to introduce new products, services, and management systems and then deliver better innovation outcomes. Formally:

H1: HRPs are positively related to innovation. 


\section{Human Resource Practices and Entrepreneurial Creativity}

SMEs engage entrepreneurial participation through creativity. SMEs need to utilize the HRP approach to acquire and reinforce employees' creativity (Binyamin \& Carmeli, 2010; Bamberger, Bacharach, \& Dyer 1989). As knowledge, abilities, and skills are specific for each organization, SMEs use HRPs to manage the set of knowledge, abilities, and skills that they have (Gimmon \& Levie, 2010; Storper \& Scott, 2009). The sub-variables of HRPs, namely compensation, recruitment, training and development, and performance appraisal, are associated with increased satisfaction, through innovation and entrepreneurial creativity (Gunday et al., 2011). Small and medium enterprises use HRPs to give entrepreneurs the skills, resources, and wisdom they need to improve their creativity. Thus, HRPs is a crucial element for SMEs in terms of enhancing creativity.

A robust employee recruitment system can help SMEs in determining and mobilizing the qualifications and competencies of employees to perform the required work. Also, employers' training tends to influence creativity development. A variety of training programmes helps employers to learn new skills, including innovative skills (Nonaka \& Takeuchi, 1995). Thus, training programmes for entrepreneurs influences entrepreneurial creativity (Binyamin \& Carmeli, 2010).

Human resource practices enable entrepreneurs to engage in and contribute to creativity and innovation. Entrepreneurs have the opportunity to create new concepts, thereby enhancing creativity and innovation (Gronum et al., 2012; Anderson et al., 2014). Furthermore, HRPs motivate entrepreneurs to be creative in developing their business enterprise. Highly qualified human resources encourage SME development in terms of entrepreneurial creativity. Thus, HRPs positively affect entrepreneurial creativity. Formally:
$H 2$. HRPs relate positively to entrepreneurial creativity.

\section{Entrepreneurial Creativity and Innovation}

Innovation involves improving existing products, services, and instituting new administrative systems so that a source of competitive advantage emerges (Martins \& Terbalanche, 2003; Chen $\&$ Huang, 2009). The entrepreneur can use their creative ability to leverage innovation (Subramaniam \& Youndt, 2005). SMEs require a certain level of entrepreneurial creativity. They improve their ability to respond, change, and develop creative concepts and innovations (Scarbrough, 2003). Entrepreneurial creativity facilitates communication and improves innovation (Gumusluoglu \& Ilsev, 2009). Thus, entrepreneurial creativity encourages innovation.

Previous research has suggested that the sharing of the results of entrepreneurial creativity can lead to an increase in SME innovation (Burch, Pavelis, \& Port, 2008; Scott \& Bruce, 1994; Somech \& Zahavy, 2013). Creativity exists within different individuals and levels of SMEs, so employers regularly need to create new motivations to foster this creativity (Fairbank \& William, 2001; Yeh-Yun Lin \& Liu, 2012). Employers' creativity enhances their organizational skills, which can be applied to the products and services offered (Martins \& Terbalanche, 2003). Entrepreneurial creativity improves efficiency and reduce overlap (YehYun Lin and Liu, 2012). Thus, SMEs can accelerate the development of new products and services and also create innovative production and administrative systems (Chen \& Huang, 2009).

Thus, this study suggests that the capacities of entrepreneurial creativity such as acquisition and sharing contribute positively to SME innovation. With entrepreneurial creativity, SMEs can create the innovative products and services. Formally:

$H 3$. Entrepreneurial creativity impacts positively on innovation. 


\section{The Mediating Effect of Entrepreneurial Creativity}

The previous hypothesis links the HRPs, entrepreneurial creativity, and innovation. In light of the above discussion it is implicit that HRPs have an effect on SME innovation through entrepreneurial creativity. Small and medium enterprises can use HRPs to improve the ability level such as acquisition of knowledge, application, and sharing, which is in turn, raise entrepreneurs' creativity to increase employees' innovation. Thus, this research shows that entrepreneurial creativity plays a role in a mediating the link between HRPs (the independent variable) and innovation (dependent variables). The following formal hypothesis is therefore proposed:

H4. The effect of HRPs on innovation is mediated through entrepreneurial creativity.

\section{Methodology}

\section{Data Collection and Sample}

This research is survey-based and used a questionnaire to collect data that was then tested for its validity and to find support or otherwise for the above research hypotheses. The questionnaire was designed to obtain demographic information, and data on the relationship between the HRPs variable, entrepreneurial innovation variable, and innovation variable. All the variables were investigated via a series of statements that required responses based on a five-point Likert-style scale which ranged from 'strongly disagree' to 'strongly agree'. The sample frame of this study included 300 top SMEs in Jakarta, Indonesia, as defined by the Ministry of SMEs and Cooperatives. This study used simple random sampling to choose 181 SMEs from among those 300 enterprises. A total of 181 questionnaires were then distributed to these SMEs' entrepreneurs who were asked to completed the questionnaire adjust to the subject matter. Out of the 181 questionnaires, nine were incomplete, leaving 172 correct and complete questionnaires for further data analysis.

\section{Innovation}

In this research, the innovation dimensions are managerial and innovation performance. Ibarra (1993) states that companies' achievements are reflected in the development and implementation of innovation activities on a seven-item scale questionnaire. The coefficient of Cronbach's alpha indicates that the internal consistency of action on workers is higher than the suggested value of 0.70 (Hair, Black, Babin, Anderson, 2014). Specific factors include four items for measuring perceptions of environmental change and innovative management $(\alpha=0.903)$. The technical factor consists of three measurement items: The development of new company technologies, the inclusion of technology into new products, and the implementation of new processes to improve quality and lower cost ( $\alpha$ $=0.891)$.

\section{Human Resource Practices}

The study adopted four factors to reflect HRPs, namely recruitment, training and development, performance appraisal, and compensation, and assessed them using a 16-item scale. According to Hair, et al., (2014) coefficients of the Cronbach's alpha in parentheses show to measure the internal consistency reliability in the four factors are all higher of the required value of 0.70 . The recruitment factor builds in three indicators relating to recruitment selection, abilities, and future capacity $(\alpha=0.811)$. For performance appraisal, the study used three indicators, namely development focus, result assessment, and behavior evaluation ( $\alpha=$ 0.905). The compensation factor includes three indicators, namely profit-sharing rate, incentive pay, and the link between performance and reward $(\alpha=0.948)$. The training and development factor includes four indicators: the availability of formal training, comprehensive training policies, training of new staff, and training in problem-solving capacity $(\alpha=$ 0.898). 


\section{Entrepreneurial Creativity}

Hills, Lumpkin, and Singh (1997) and Puhakka (2005) measure entrepreneurial creativity using four factors: personality, personal perception, family background, and social environment. According to Hair, et al., (2014) coefficients of the Cronbach's alpha in parentheses show to measure the internal consistency reliability in the four factors are all higher of the required value of 0.70 . The personality factor consists of two items regarding ability and aspiration ( $\alpha=0.821$ ), while the personal perception factor consists of two indicators regarding solutions and problem solving $(\alpha=0.890)$. The family background factor consists of two items regarding sensitiveness and receptiveness $(\alpha=$ 0.981 ). The social environment factor consists of two items regarding improvement and code of conduct $(\alpha=0.898)$.

\section{Control Variables}

The size and age of SMEs can affect innovation as well as the deployment of resources. Also,
SMEs in diverse industries can behave differently regarding their creativity and innovation. Thus, this research includes these three variables as control variables for measuring effects among variables. This research measures the size of SMEs ( small $=1$, medium $=2$ ) and the age of the company (calculated as the years number from the date of establishment). As for industry, three attribute variables show SMEs industry type (manufacturing $=1$, service industry $=2$, and trade $=3)$.

\section{Results}

The aim of this research is to understand the related HRPs to entrepreneurial creativity and the effect on innovation. Table 1 presents the means $(M)$, standard deviations $(S D)$, and the correlation between the studied variables. This research also applies variance inflation factors (VIFs) to study correlation of multicollinearity. According to Hair et al. (2014) VIF values should be ranging from 1.25 to 2.80 within appropriate limits, thus there is no need to be concerned about multicollinearity relationships.

\section{Table 1}

\section{Means, Standard Deviations, and Correlations}

\begin{tabular}{|c|c|c|c|c|c|c|c|c|c|c|c|c|c|c|}
\hline Variables & Mean & S.D. & 1 & 2 & 3 & 4 & 5 & 6 & 7 & 8 & 9 & 10 & 11 & 12 \\
\hline 1. SME age & 8.72 & 2.78 & & & & & & & & & & & & \\
\hline 2. SME size & 1.52 & 0.50 & -0.06 & & & & & & & & & & & \\
\hline 3. Industry type $\mathrm{e}^{\mathrm{a}}$ & 2.08 & 0.75 & 0.08 & 0.32 & & & & & & & & & & \\
\hline 4. Recruitment & 2.49 & 0.50 & -0.09 & 0.94 & 0.34 & & & & & & & & & \\
\hline $\begin{array}{l}\text { 5. Performance } \\
\text { appraisal }\end{array}$ & 2.64 & 0.49 & 0.10 & 0.15 & 0.04 & 0.57 & & & & & & & & \\
\hline $\begin{array}{l}6 . \\
\text { Compensation }\end{array}$ & 3.53 & 0.84 & 0.12 & 0.15 & 0.04 & 0.51 & 0.50 & & & & & & & \\
\hline $\begin{array}{l}\text { 7. Training and } \\
\text { development }\end{array}$ & 3.08 & 0.83 & -0.08 & 0.04 & 0.02 & 0.06 & 0.11 & 0.23 & & & & & & \\
\hline 8. Personality & 3.52 & 0.86 & 0.04 & 0.09 & 0.09 & 0.23 & 0.04 & 0.46 & 0.32 & & & & & \\
\hline $\begin{array}{l}\text { 9. Personal } \\
\text { perception }\end{array}$ & 3.08 & 0.64 & -0.02 & -0.12 & -0.14 & 0.04 & 0.14 & -0.17 & 0.12 & -0.18 & & & & \\
\hline $\begin{array}{l}\text { 10. Family } \\
\text { background }\end{array}$ & 3.52 & 0.85 & -0.02 & 0.11 & -0.02 & 0.13 & 0.08 & 0.40 & 0.20 & 0.37 & -0.18 & & & \\
\hline
\end{tabular}

(continued) 


\begin{tabular}{lcccccccccccccccc}
\hline \multicolumn{1}{c}{ Variables } & Mean & S.D. & $\mathbf{1}$ & $\mathbf{2}$ & $\mathbf{3}$ & $\mathbf{4}$ & $\mathbf{5}$ & $\mathbf{6}$ & $\mathbf{7}$ & $\mathbf{8}$ & $\mathbf{9}$ & $\mathbf{1 0}$ & $\mathbf{1 1}$ & $\mathbf{1 2}$ & \\
\hline $\begin{array}{l}\text { 11. Social } \\
\text { environment }\end{array}$ & 3.08 & 0.82 & 0.07 & 0.08 & 0.06 & 0.14 & 0.17 & 0.23 & 0.06 & 0.21 & 0.19 & 0.24 \\
$\begin{array}{l}\text { 12. } \\
\begin{array}{l}\text { Administrative } \\
\text { innovation }\end{array}\end{array}$ & 3.19 & 0.85 & 0.01 & 0.21 & 0.15 & 0.16 & 0.24 & 0.10 & 0.01 & 0.08 & 0.24 & 0.17 & 0.45 \\
$\begin{array}{l}\text { 13. Technical } \\
\text { innovation }\end{array}$ & 3.42 & 0.87 & 0.06 & 0.20 & 0.28 & 0.02 & -0.01 & 0.22 & 0.22 & 0.27 & -0.12 & 0.44 & 0.31 & 0.26 \\
\hline
\end{tabular}

Note: $\mathrm{n}=172$ (two-tailed test). Correlations with absolute value greater than 0.16 are significant at $\mathrm{p}<0.05$, and those greater than 0.21 are significant at $\mathrm{p}<0.01$.

${ }^{a}$ Control variable coded as manufacturing industry, 1 ; service, 2 ; trade, 3 .

Table 2 provides the regression analyses results on the effect of HRPs and entrepreneurial creativity on innovation. Table 2 presents the

Table 2

\section{Results of Regression Analysis of Innovation}

\begin{tabular}{|c|c|c|c|c|c|c|c|c|}
\hline \multirow[t]{2}{*}{ Variable } & \multicolumn{4}{|c|}{ Administrative innovation } & \multicolumn{4}{|c|}{ Technical innovation } \\
\hline & Model Ia & Model IIa & Model IIIa & Model IVa & Model Ib & Model IIb & Model IIIb & $\begin{array}{l}\text { Model } \\
\text { IVb }\end{array}$ \\
\hline \multicolumn{9}{|l|}{ Control variables } \\
\hline SME age & -0.23 & 0.15 & $0.16^{*}$ & -0.02 & 0.04 & 0.02 & 0.03 & 0.04 \\
\hline SME size & 0.18 & -0.02 & -0.25 & 0.14 & 0.12 & $-0.13^{*}$ & -0.02 & -0.07 \\
\hline Industry type & 0.21 & 0.10 & 0.11 & 0.11 & 0.17 & $0.24 * *$ & $0.20^{* *}$ & $0.23 *$ \\
\hline \multicolumn{9}{|l|}{ HRPs } \\
\hline $\begin{array}{l}\text { Recruitment and } \\
\text { selection }\end{array}$ & & $0.31 * * *$ & & 0.02 & & $0.24 * *$ & & 0.03 \\
\hline $\begin{array}{l}\text { Performance } \\
\text { appraisal }\end{array}$ & & $0.22 * *$ & & $0.18^{* *}$ & & -0.15 & & 0.09 \\
\hline Compensation & & -0.10 & & -0.14 & & $0.25 * *$ & & 0.02 \\
\hline $\begin{array}{l}\text { Training and } \\
\text { development }\end{array}$ & & 0.06 & & -0.08 & & $0.27 * *$ & & 0.13 \\
\hline \multicolumn{9}{|l|}{$\begin{array}{l}\text { Entrepreneurial } \\
\text { creativity }\end{array}$} \\
\hline Personality & & & $0.31 * * *$ & $0.21 * * *$ & & & $0.35^{* * *} *$ & $0.31 * * *$ \\
\hline Personal perception & & & $0.33 * * *$ & $0.32 * * *$ & & & $0.22 * * *$ & $0.39 * * *$ \\
\hline Family background & & & $0.22 * *$ & $0.15^{*}$ & & & $0.26^{* * *}$ & $0.34 * * *$ \\
\hline Social environment & & & $0.25 * *$ & $0.26^{* * * *}$ & & & $0.29^{* *}$ & $0.21 *$ \\
\hline$R^{2}$ & 0.06 & 0.60 & 0.54 & 0.62 & 0.09 & 0.54 & 0.24 & 0.35 \\
\hline$F$ & $3.26^{*}$ & $22.79 * * *$ & $19.71 * * *$ & $26.96 * * *$ & 1.19 & $25.45 * * *$ & $11.36 * * *$ & $17.88 * * *$ \\
\hline
\end{tabular}

Note: $\mathrm{n}=172$ (two-tailed test). Standardized coefficients are reported. ${ }^{*} p<0.05,{ }^{* * *} p<0.01,{ }^{* * * * k} p<0.001$. 
Models IIa and IIb in Table 2 show the direct effects of HRPs on innovation as an endogenous variable. It is significant at $\left(R^{2}=0.60\right.$ and 0.54 , $p<0.001)$ and explained $54.0 \%$ of the control variables variance. Recruitment and selection, performance evaluation, compensation, and training and development are positive and significant for management's ability to innovate $(p<0.001, p<0.05, p<0.01)$. Likewise, recruitment and selection, performance evaluation, compensation, and training and development have a moderate effect on innovation $(p<0.01)$. Similarly, recruitment and selection, performance evaluation, compensation, and training and development have a moderate effect on innovation $(p<0.01)$. These findings suggest that SMEs can achieve a higher level of innovation levels when they have adequate recruitment and selection, performance appraisal, compensation, and training and development in the workplace. These results are quite supportive of hypothesis 1 , which states that HRPs are positively related to innovation. These results are quite supportive of hypothesis 1, which states that HRPs are positively related to innovation.

Table 3 shows the impact of HRPs on entrepreneurial creativity. Models Va, Vb, $\mathrm{Vc}$, and $\mathrm{Vd}$ are basic models that contain only control variables. Models VIa, VIb, VIc, and VId show the relationship between HRPs and entrepreneurial creativity. These four models are all significant at the $\mathrm{p}<0.001$ level $\left(\mathrm{R}^{2}=0.63\right.$, $0.65,0.20$, and 0.56 ) and explain 57\%; 63\%; $19 \%$ and $55 \%$ of variance over what the control variables explain.

The coefficients of recruitment and performance appraisal are significant and positive for personality, personal perception, family background, and social environment $(p<0.001)$. Compensation has a positive and significant effect on personality $(p<0.05, p<0.01)$ and personality can be felt $(p<0.001, p<0.05, p$ $<0.01)$. Training and development is positive significant for family background $(p<0.001, p<$
$0.05, \mathrm{p}<0.01)$ and social environment $(p<0.05$, $p<0.01)$. These discoveries suggest that there is a higher innovation level among employers when they attract and choose high-quality employees, invest in training programmes, give opportunities participation to employees, and synchronize merit systems. The result supports hypothesis 2, which affirms that HRPs effect positively on entrepreneurial creativity.

This study also examines how entrepreneurial creativity influences innovation. In this respect, Models IIIa and IIIb in Table 2 are both significant at the $\mathrm{p}<0.001$ level $\left(\mathrm{R}^{2}=0.54\right.$ and 0.24 ) and explain an additional $48 \%$ and $15 \%$ of variance over what the control variables alone explain. The variables are significant and positive for technical management and innovation are personality $(r=0.31, p<0.001)$, personal perception $(r=0.33, p<0.001)$, family background $(r=0.22, p<0.01)$, and social environment $(r=0.25, p<0.01)$. It shows that SMEs will innovate better when they develop their entrepreneurial creativity in personality, personal perception, family background and social environment. In short, the four indicators of entrepreneurial creativity as expected have significant implications for innovation. Thus, the findings support hypothesis 3 .

Baron and Kenny (1986) state that entrepreneurial creativity mediates the relationship between HRPs and innovation. To examine this assertion, the current study follows four steps. The first step involves examining, the independent variable related to the dependent variable. As shown in Models IIa and IIb in Table 2, four HRPs are effecting on innovation.

The second step involves investigating the mediating role of entrepreneurial creativity on HRPs. The results of Models VIa to VId in Table 3 show that HRP factors have four positive and significant effects on entrepreneurial creativity. The third step examine the relationship between the mediating variable and the dependent 
variable. Models IIIa and IIIb in Table 2 show entrepreneurial creativity has a positive and significant effect on innovation. In the models to examine whether it reduces the effects of the antecedents to not-significance. As shown by Models IVa and IVb in Table 2, the coefficients for the entrepreneurial creativity factors are positive and significant, indicating the direct effect of entrepreneurial creativity on innovation. Furthermore, entrepreneurial creativity significantly reduces the effect of the HRP factors on HRPs and innovation variables, most of them to non-significance. The results show that the inclusion of entrepreneurial creativity factors strengthens the relationship between HRPs and innovation. Thus, entrepreneurial creativity plays a mediating role in the relationship between HRPs and innovation and hypothesis 4 is supported.

Table 3

Results of Regression Analyses of Entrepreneurial Creativity

\begin{tabular}{|c|c|c|c|c|c|c|c|c|}
\hline \multirow[t]{2}{*}{ Variable } & \multicolumn{2}{|c|}{ Personality } & \multicolumn{2}{|c|}{ Personal Perception } & \multicolumn{2}{|c|}{ Family Background } & \multicolumn{2}{|c|}{ Social Environment } \\
\hline & $\begin{array}{c}\text { Model } \\
\text { Va }\end{array}$ & $\begin{array}{c}\text { Model } \\
\text { VIa }\end{array}$ & $\begin{array}{c}\text { Model } \\
\text { Vb }\end{array}$ & $\begin{array}{l}\text { Model } \\
\text { VIb }\end{array}$ & $\begin{array}{c}\text { Model } \\
\text { Vc }\end{array}$ & Model VIc & $\begin{array}{c}\text { Model } \\
\text { Vd }\end{array}$ & Model VId \\
\hline \multicolumn{9}{|l|}{ Control variables } \\
\hline SME age & -0.02 & 0.03 & -0.01 & -0.03 & -0.01 & 0.06 & 0.06 & 0.03 \\
\hline SME size & 0.07 & -0.01 & -0.08 & 0.05 & -0.02 & $-0.11 *$ & 0.06 & 0.28 \\
\hline Industry type & $0.24 * *$ & 0.07 & -0.11 & 0.12 & 0.04 & 0.03 & 0.03 & 0.04 \\
\hline \multicolumn{9}{|l|}{ HRPs } \\
\hline $\begin{array}{l}\text { Recruitment and } \\
\text { selection }\end{array}$ & & $0.33^{* * *} *$ & & $0.34 * * *$ & & -0.04 & & $0.37 * * *$ \\
\hline Performance appraisal & & 0.08 & & 0.08 & & -0.14 & & $0.36 * * *$ \\
\hline Compensation & & 0.06 & & $0.37 * * *$ & & 0.47 & & $0.22 *$ \\
\hline $\begin{array}{l}\text { Training and } \\
\text { development }\end{array}$ & & $0.18 *$ & & 0.17 & & 0.11 & & $0.31 * * *$ \\
\hline$R^{2}$ & 0.06 & 0.63 & 0.02 & 0.65 & 0.01 & 0.20 & 0.01 & 0.56 \\
\hline$F$ & $4.77 * *$ & $21.44 * * *$ & 1.59 & $24.37 * * *$ & 0.86 & 6.18 & 0.72 & $21.63 * * *$ \\
\hline
\end{tabular}

Note: $\mathrm{n}=172$ (two-tailed test). Standardized coefficients are reported.

" $\mathrm{p}<0.05,{ }^{* *} \mathrm{p}<0.01{ }^{* * * *} \mathrm{p}<0.001$.

\section{Discussion}

Human resource practices have a powerful effect on innovation through entrepreneurial creativity. Moreover, entrepreneurial creativity stimulates innovation that ultimately results in better innovation. Human resource practices are mediated by entrepreneurial creativity and this increases innovation.
The current study extends existing knowledge on human resource practices (HRPs) and its innovation properties, by showing that an entrepreneurial creativity can boost entrepreneurs positive perceptions of their business innovation context. Our results indicated that a human resource practice (HRPs) oriented towards recruitment, performance appraisal, compensation, and training and development can play a key role in shaping entrepreneurs' 
creativity perceptions of their innovation context (e.g., by enhancing perceptions of available human resources).

Importantly, a positive HRPs is deemed to be effective in innovative business environments, thereby providing to some extent an alternative for business re-design interventions (Nielsen, Randall, and Christensen, 2010). With the current contribution, we add to the entrepreneurial creativity on the relationship between HRPs and innovation.

Moreover, in line with the tenets of the Broadenand-built theory (Frederickson, 2001), the second major finding of our study shows that entrepreneurs who are engaged (in a state of positive affect), in time, report experiences of a more positive and innovation business context. SME's that place a high value on creating innovation work environment are advised to nurture entrepreneurs creativity and to encourage HRPs to lead by the principles of HRPs. SMEs may facilitate this by providing HRPs programs that promote HRPs in daily interactions with entrepreneurs. HRPs to master the particular skill set required to support entrepreneurs creativity seems practical because empirical evidence from the past decade has shown that HRPs are malleable and subject to change by means of professional trainings (Jackson \& Lindsay, 2010; Nielsen, Randall, \& Christensen, 2010).

There are some limitations to the current study. First, owing to the homogeneity of the data (i.e., collected among entrepreneurs undertaking in Indonesia SME) the generalizability of our findings and conclusions is limited to entrepreneurs undertaking in the Indonesia SME. Therefore, caution is called for when applying our conclusions to other. Second, the data for this study was collected by means of selfreported measures. This may raise a concern for common method bias and measurement error, because the use of self-reports may result in inflated estimation of the study effects (\& Zapf, 1994). However, Spector (2006) argued against this concern, by pointing out that common method bias issues are usually overstated in this kind of survey research.

Moreover, in line with Conway and Lance (2010), the use of self-reports for studying perceptions of job characteristics and occupational well-being in human resources research is appropriate. This is because experiences of the work context and of occupational well-being are subjective by their very nature and are thus best measured by tapping into individual's perceptions. To test the robustness of our model, future studies might wish to replicate it using data collected from various actors such as evaluations from colleagues, supervisors and external parties when measuring constructs such as intrapreneur leadership, entrepreneurship resources, and job engagement.

\section{Conclusion}

This study tested the mediating role of entrepreneurial creativity between HRPs and innovation. Human resources are valuable asset for SMEs that want to achieve superior innovation and sustainable competitive advantage. The research outcome highlights the importance of the mediating role of entrepreneurial creativity in the relationship between HRPs and innovation. The results contribute to the conceptual development by explaining the effect of HRPs and entrepreneurial creativity on innovation. A key practical implication of the outcome of this research is that employers should consider finding ways to better manage their human resources in order to achieve a greater degree of success.

The findings also suggest the relationship that has to be considered in developing appropriate HRPs in the Indonesian SME. For example, in the business risk and uncertainty, it may be 
difficult for entrepreneurs to seek an appropriate creativity to be instilled in the SME. However, in the increased productivity, the HRPs should focus on entrepreneurial creativity so as to enhance the innovation of the SME. This research has also provided us with a better understanding of the relationships of these factors in order to enhance entrepreneurs effectiveness and SME success.

\section{References}

Ait Razouk, A. (2011). High-performance work systems and performance of French smalland medium-sized enterprises: Examining causal order. The International Journal of Human Resource Management, 22(02), 311-330.

Alpkan, L., Bulut, C., Gunday, G., Ulusoy, G., \& Kilic, K. (2010). Organizational support for intrapreneurship and its interaction with human capital to enhance innovative performance. Management Decision, 48(5), 732-755.

Anderson, N., Potočnik, K., \& Zhou, J. (2014). Innovation and creativity in organizations: A state-of-the-science review, prospective commentary, and guiding framework. Journal of Management, 40(5), 12971333.

Bamberger, P., Bacharach, S., \& Dyer, L. (1989). Human resources management and organizational effectiveness: High technology entrepreneurial startup firms in Israel. Human Resource Management, 28(3), 349-366.

Baron, R. M., \& Kenny, D. A. (1986). The moderator-mediator variable distinction in social psychological research: Conceptual, strategic, and statistical considerations. Journal of Personality and Social Psychology, 51(6), 1173.

Binyamin, G., \& Carmeli, A. (2010). Does structuring of human resource management processes enhance employee creativity? The mediating role of psychological availability. Human Resource Management, 49(6), 999-1024.
Burch, G. S. J., Pavelis, C., \& Port, R. L. (2008). Selecting for creativity and innovation: The relationship between the innovation potential indicator and the team selection inventory. International Journal of Selection and Assessment, 16(2), 177181.

Conway, J. M., \& Lance, C. E. (2010). What reviewers should expect from authors regarding common method bias in organizational research. Journal of Business and Psychology, 25, 325-334.

Chang, S., Gong, Y., \& Shum, C. (2011). Promoting innovation in hospitality companies through human resource management practices. International Journal of Hospitality Management, 30(4), 812-818.

Chaston, I., \& Sadler-Smith, E. (2012). Entrepreneurial cognition, entrepreneurial orientation and firm capability in the creative industries. British Journal of Management, 23(3), 415-432.

Chen, C. J., \& Huang, J. W. (2009). Strategic human resource practices and innovation performance-The mediating role of knowledge management capacity. Journal of Business Research, 62(1), 104-114.

Colombo, M. G., Piva, E., \& Rossi-Lamastra, C. (2014). Open innovation and withinindustry diversification in small and medium enterprises: The case of open source software firms. Research Policy, 43(5), 891-902.

Cooke, F. L., Saini, D. S., \& Wang, J. (2014). Talent management in China and India: A comparison of management perceptions and human resource practices. Journal of World Business, 49(2), 225-235.

De Jong, J., \& Den Hartog, D. (2010). Measuring innovative work behaviour. Creativity and Innovation Management, 19(1), 2336. 
De Winne, S., \& Sels, L. (2010). Interrelationships between human capital, HRM and innovation in Belgian start-ups aiming at an innovation strategy. The International Journal of Human Resource Management, 21(11), 1863-1883.

Edwards, T., Delbridge, R., \& Munday, M. (2005). Understanding innovation in small and medium-sized enterprises: A process manifest. Technovation, 25(10), 1119-1127.

Fairbank, J. F., \& Williams, S. D. (2001). Motivating creativity and enhancing innovation through employee suggestion system technology. Creativity and Innovation Management, 10(2), 68-74.

Frese, M., \& Zapf, D. (1994). Methodological issues in the study of work stress: Objective vs subjective measurement of work stress and the question of longitudinal studies. In C. L.

Cooper \& I. T. Robertson (Eds.), Causes, coping and consequences of stress at work (pp. 375-411). Oxford, England: John Wiley \& Sons.

Fredrickson, B. L. (2001). The role of positive emotions in positive psychology: The broadenand-build theory of positive emotions. American Psychologist, 56(3), 218-226.

Gimmon, E., \& Levie, J. (2010). Founder's human capital, external investment, and the survival of new high-technology ventures. Research Policy, 39(9), 12141226.

Grimaldi, M., Quinto, I., \& Rippa, P. (2013). Enabling open innovation in small and medium enterprises: A dynamic capabilities approach. Knowledge and Process Management, 20(4), 199-210.

Gronum, S., Verreynne, M. L., \& Kastelle, T. (2012). The role of networks in small and medium sized enterprise innovation and firm performance. Journal of Small Business Management, 50(2), 257-282.
Gumusluoglu, L., \& Ilsev, A. (2009). Transformational leadership, creativity, and organizational innovation. Journal of business research, 62(4), 461-473.

Gunday, G., Ulusoy, G., Kilic, K., \& Alpkan, L. (2011). Effects of innovation types on firm performance. International Journal of Production Economics, 133(2), 662676.

Hair Jr, J. F., Black, W. C., Babin, J. B., \& Anderson, R. E. (2014) Multivariate data analysis. Upper Saddle River, NJ: Prentice-Hall.

Hills, G.E., Lumpkin, G. T., \& Singh, R.P.(1997). Opportunity recognition: Perceptions and behaviors of entrepreneurs. Frontiers of Entrepreneurship Research, 17(4), 168182.

Herzog, T. (2010). Strategic management of coopetitive relationships in CoPS-related industries. In S. Yami, S. Castaldo, G. B. Dagnino and F. Le Roy (eds), Coopetition: Winning Strategies for the 21st Century, pp. 200-216. Cheltenham: Edward Elgar.

Hotho, S., \& Champion, K. (2011). Small businesses in the new creative industries: Innovation as a people management challenge. Management Decision, 49(1), 29-54.

Ibarra, H. (1993). Network centrality, power, and innovation involvement: Determinants of technical and administrative roles. Academy of Management Journal, 36(3), 471-501.

Ismaila, AI., Abdul-Halim, A., \& Joardera, MH. (2017). Filling up the HRM 'Black Box'; do creativity and management philosophy matter? Management Science Letters 7 (4), 163-176.

Jiang, J., Wang, S., \& Zhao, S. (2012). Does HRM facilitate employee creativity and organizational innovation? A study of Chinese firms. The International Journal of Human Resource Management, 23(19), 4025-4047. 
Jimenez-Jimenez, D., \& Sanz-Valle, R. (2005). Innovation and human resource management fit: An empirical study. International Journal of Manpower, 26(4), 364-381.

Jackson, R. J., \& Lindsay, D. R. (2010). Lessons for experience: Why wait? Industrial and Organizational Psychology, 3, 48-51.

Laursen, K., \& Foss, N. J. (2003). New human resource management practices, complementarities and the impact on innovation performance. Cambridge Journal of economics, 27(2), 243-263.

Man, T. W., Lau, T., \& Chan, K. F. (2002). The competitiveness of small and medium enterprises: A conceptualization with focus on entrepreneurial competencies. Journal of Business Venturing, 17(2), 123-142.

Martins, E. C., \& Terblanche, F. (2003). Building organizational culture that stimulates creativity and innovation. European Journal of Innovation Management, 6(1), 64-74.

McAdam, R., Moffett, S., Hazlett, S. A., \& Shevlin, M. (2010). Developing a model of innovation implementation for UK SMEs: A path analysis and explanatory case analysis. International Small Business Journal, 28(3), 195-214.

Nielsen, K., Randall, R., \& Christensen, K. B. (2010). Does training managers enhance the effects of implementing teamworking? A longitudinal, mixed methods field study. Human Relations, 63, 17191741.

Nonaka, I., \& Takeuchi, H. (1995). The knowledge-creating company: How Japanese companies create the dynamics of innovation. New York: Oxford University Press.

Perry-Smith, J. E. (2006). Social yet creative: The role of social relationships in facilitating individual creativity. Academy of Management Journal, 49(1), 85-101.
Puhakka, V. (2005). The role of intellectual capital in opportunity recognition of entrepreneurs. Oulu: University of Oulu, Department of Information Processing Science.

Scarbrough, H. (2003). Knowledge management, HRM and the innovation process. International Journal of Manpower, 24(5), 501-516.

Scott, S. G., \& Bruce, R. A. (1994). Determinants of innovative behavior: A path model of individual innovation in the workplace. Academy of Management Journal, 37(3), 580-607.

Sheehan, M. (2014). Human resource management and performance: Evidence from small and medium-sized firms. International Small Business Journal, 32(5), 545-570.

Somech, A., \& Drach-Zahavy, A. (2013). Translating team creativity to innovation implementation: The role of team composition and climate for innovation. Journal of Management, 39(3), 684-708.

Stjernholm Madsen, A., \& Ulhøi, J. P. (2005). Technology innovation, human resources and dysfunctional integration. International Journal of Manpower, 26(6), 488-501.

Storper, M., \& Scott, A. J. (2009). Rethinking human capital, creativity and urban growth. Journal of Economic Geography, 9(2), 147-167.

Subramaniam, M., \& Youndt, M. A. (2005). The influence of intellectual capital on the types of innovative capabilities. Academy of Management Journal, 48(3), 450-463.

Spector, P. E. (2006). Method variance in organizational research truth or urban legend? Organizational Research Methods, 9(2), 221-232.

Terziovski, M. (2010). Innovation practice and its performance implications in small and medium enterprises (SMEs) in the manufacturing sector: A resource-based view. Strategic Management Journal, 31(8), 892-902. 
Valaei, N., \& Rezaei, S. (2017). Does Web 2.0 utilisation lead to knowledge quality, improvisational creativity, compositional creativity, and innovation in small and medium-sized enterprises? A sensemaking perspective. Technology Analysis \& Strategic Management, 29(4), 381394.

Voss, G. B., \& Voss, Z. G. (2013). Strategic ambidexterity in small and medium-sized enterprises: Implementing exploration and exploitation in product and market domains. Organization Science, 24(5), 1459-1477.
Yeh-Yun Lin, C., \& Liu, F. C. (2012). A crosslevel analysis of organizational creativity climate and perceived innovation: The mediating effect of work motivation. European Journal of Innovation Management,15(1), 55-76.

Youndt, M. A., Snell, S. A., Dean, J. W., \& Lepak, D. P. (1996). Human resource management, manufacturing strategy, and firm performance. Academy of Management Journal, 39(4), 836-866. 